\title{
DDX1 wt Allele
}

National Cancer Institute

\section{Source}

National Cancer Institute. DDX1 wt Allele. NCI Thesaurus. Code C54428.

Human DDX1 wild-type allele is located in the vicinity of $18 \mathrm{q} 21.3$ and is approximately 40 $\mathrm{kb}$ in length. This allele, which encodes ATP-dependent RNA helicase DDX1 protein, is involved in the regulation of processes that are dependent on the alteration of RNA secondary structure. 